\title{
Outbreaks of hepatitis A in Poland are often connected with other infections
}

\author{
Pola Tochman ${ }^{1}$, Tomasz Mikula², Dagny Krankowska², Mariusz Sapula², Magdalena M. Suchacz ${ }^{2}$, \\ Alicja Wiercinska-Drapalo \\ ${ }^{1}$ Students' Science Society of the Department of Infectious and Tropical Diseases and Hepatology, \\ Medical University of Warsaw, Poland \\ ${ }^{2}$ Department of Infectious and Tropical Diseases and Hepatology, Medical University of Warsaw, Poland
}

\begin{abstract}
Introduction: The amount of reported hepatitis A cases in Europe increased significantly in 2017. The main cause of the latest outbreak is transmission by faecal-oral contact during sexual activity, mostly among men who have sex with men (MSM). The aim was to analyze the main co-infections in adult patients with hepatitis A virus (HAV) infection.

Material and methods: We analyzed the records of 55 patients with HAV infection. In studied group, we evaluated gender, age, duration of hospitalization, blood cell count, activity of liver enzymes, total bilirubin, international normalized ratio (INR), and serologic tests for human immunodeficiency virus (HIV), hepatitis B virus (HBV), hepatitis C virus (HCV), and syphilis.

Results: Ninety five percent of analyzed patients were male, from whom almost 70\% were MSM. The median age was 31 years. The median duration of hospitalization was 6 days. Serological tests for other infections were positive for HIV in 11 patients $(11 / 53 ; 20.75 \%)$, for $\mathrm{HBV}$ in 3 patients $(3 / 53 ; 5.66 \%)$ and for syphilis for 2 patients $(2 / 33 ; 6.06 \%)$. None of the 52 tested patients were HCV positive.
\end{abstract}

Conclusion: The study showed that HAV infection among young MSM often co-exist with other sexually transmitted diseases: syphilis, hepatitis B and HIV infection.

HIV AIDS Rev 2019; 18, 1: 40-43 DOI: https://doi.org/10.5114/hivar.2019.84117

Key words: HIV, hepatitis B, hepatitis A, outbreak, syphilis.

\section{Introduction}

Hepatitis A is one of the world's most common infectious disease, caused by the hepatitis A virus (HAV), member of the Picornaviridae family. Humans are the natural hosts of the virus, 4 out of 7 genotypes are infectious for people [1]. The way of transmission is a fecal-oral route. People can be infected by direct contact with others or consuming contaminated food and water. The risk factors include

Address for correspondence: Magdalena M. Suchacz, MD, Department of Infectious and Tropical Diseases and Hepatology, Medical University of Warsaw, 37 Wolska St., 01-201 Warsaw, Poland, e-mail: m.dabrowska@op.pl overcrowding, poverty, bad sanitary conditions, problems with access to fresh water. It typically occurs in developing countries, more often among children [1]. Hepatitis A is also classified as a sexually transmitted disease, transmitted by the fecal-oral contact during sexual activity. Last years have brought few outbreaks among the MSM (men who have sex with men) population [2,3].

During the last year a significantly increased hepatitis A incidence rate has been observed in Europe. The number
Article history:

Received: 30.11.2018

Received in revised form: 01.01.2019

Accepted: 05.02.2019

Available online: 15.03.2019
International Journal of HIV-Related Problems

HIV \& AIDS

R e v i e w 
of cases reported between January and mid-August 2016 in Poland was 24. In the same period in 2017, there were 912 cases. The highest prevalence was among male patients, aged 22-40 years [2].

HAV replicates in hepatocytes, causing acute liver inflammation. Infection in children population is usually asymptomatic. Adults usually develop jaundice, fatigue, fever, diarrhea, nausea, abdominal discomfort, anorexia, pruritus. Symptoms last less than 2 months, sometimes up to 6 months. The diagnosis is made by detecting the HAV IgM antibodies in the serum. Treatment includes supportive care, hospitalization is required only in case of severe dehydration or in patients developing the signs of acute liver failure. Most patients make full recovery. The most frequent complication is cholestatic hepatitis. Hepatitis A infection cannot cause chronic liver disease [1].

The most effective way of prevention is vaccination by inactivated or live attenuated virus. The schedule includes two doses, giving the immunity for at least 20 years. The vaccination is recommended in the regions of high incidence and among people at risk of infection like MSM, drug users, international travelers [4].

The aim of this study was to analyze the main co-infections and route of transmission among patients with hepatitis A admitted to the hospital from May to December 2017.

\section{Material and methods}

We analyzed the laboratory results of 55 adult patients with HAV IgM antibodies detected in the serum. The characteristics included gender, age, the duration of hospitalization, red blood cells count, white blood cells count, platelet count, alanine aminotransferase (ALT), aspartate aminotransferase (AST), gamma-glutamyltransferase (GGT), alkaline phosphatase (ALP), bilirubin, international normalized ratio (INR), De Ritis ratio (AST/ALT serum level). The serological test were made for other infections such as HIV, HBV, HCV and syphilis.

\section{Results}

In this study $95 \%$ of patients were male. The median age was 31 years old (range 22-52 years old). Only 7 patients were older than 40 years. Most of the patients (70\%) were MSM. The medical records confirmed the fecal-oral route of the HAV transmission during sexual activity. The median length of hospitalization was 6 days, with the longest stay for 12 days (for 2 patients).
Most of the patients with acute hepatitis A were concomitantly diagnosed for other infections. Among 53 tested patients, 11 were HIV-positive (21\%) and 3 were HBV-positive (6\%). Two out of 33 patients (6\%) had positive VDRL test indicating recently active syphilis infection. Both of them were also HIV-positive. Fifty-two patients were tested for hepatitis C, however none of them was positive. Some of the co-infections were acquired recently. The results of serological tests for other co-infections in patients with acute hepatitis A are presented in Table 1.

Table 2 shows selected laboratory abnormalities. The number of red blood cells (RBC) was elevated in one patient and reduced in two patients with median $5.1 \mathrm{M} / \mu \mathrm{l}$. White blood cells (WBC) were elevated in one, and reduced in 7 patients with median $5.2 \mathrm{~K} / \mu \mathrm{l}$. Median platelet (PLT) count was $227.5 \mathrm{~K} / \mu \mathrm{l}$, and PLT was elevated in one studied case.

The results of the biochemical tests are presented in Table 3. All 55 patients had elevated activity of alanine aminotransferase (ALT), aspartate aminotransferase (AST), and gamma-glutamyltransferase (GTP). Forty-six patients (83.6\%) had elevated activity of alkaline phosphatase (ALP). Total bilirubin concentration was elevated in all patients. Finally, the international normalized ratio (INR) was elevated in 28 patients $(50.9 \%)$.

The De Ritis ratio (AST/ALT serum level) was calculated. Fifty four patients had the De Ritis ratio value less than 1 (ALT level higher than AST level) what is typical for acute viral hepatitis. Only one patient had the AST level higher than ALT, which can suggest other causes of liver dysfunction, beyond the acute HAV-infection.

\section{Discussion}

In previous years hepatitis A occurred in Poland sporadically, mostly among children, usually no more than several

Table 1. The results of serological tests for other co-infections in patients with acute hepatitis $A$

\begin{tabular}{l|c|c|c}
\hline $\begin{array}{l}\text { Tested co- } \\
\text { infection }\end{array}$ & $\begin{array}{c}\text { No. } \\
\text { of tested } \\
\text { patients }\end{array}$ & $\begin{array}{c}\text { No. of positive } \\
\text { results }\end{array}$ & $\begin{array}{c}\% \text { of positive } \\
\text { results }\end{array}$ \\
\hline HIV & 53 & 11 & 21 \\
\hline Hepatitis B & 53 & 3 & 6 \\
\hline Syphilis & 33 & 2 & 6 \\
\hline Hepatitis C & 52 & 0 & 0 \\
\hline
\end{tabular}

Table 2. Laboratory findings in patients with acute hepatitis A

\begin{tabular}{|c|c|c|c|c|}
\hline Parameter & No. of patients & Median & Range of peak values & Reference range \\
\hline $\mathrm{RBC}(M / \mu \mathrm{l})$ & 51 & 5.1 & $4.3-6.3$ & $4.6-6.2$ \\
\hline WBC $(K / \mu l)$ & 52 & 5.1 & $3.1-11.1$ & $4.0-10.0$ \\
\hline $\mathrm{PLT}(\mathrm{K} / \mu \mathrm{l})$ & 52 & 227.5 & $56.0-410.0$ & $150.0-400.0$ \\
\hline
\end{tabular}


Table 3. Biochemical tests in patients with acute hepatitis A

\begin{tabular}{l|c|c|c|c}
\hline Parameter & No. of patients & Median & Range of peak values & $\begin{array}{c}\text { Upper limit } \\
\text { of reference range }\end{array}$ \\
\hline ALT (IU/l) & 55 & 2609.0 & $380.0-12179.0$ & 40.0 \\
\hline AST (IU/l) & 55 & 907.0 & $107.0-10790.0$ & 40.0 \\
\hline GGT (IU/l) & 55 & 227.0 & $56.0-729.0$ & 55.0 \\
\hline ALP (IU/l) & 54 & 174.5 & $80.0-443.0$ & 123.0 \\
\hline Total bilirubin $(\mu \mathrm{mol} / \mathrm{l})$ & 55 & 116.2 & $25.1-298.7$ & 17.0 \\
\hline INR & 55 & 1.2 & $0.9-1.9$ & 1.3 \\
\hline
\end{tabular}

dozen registered cases in the whole country per year. The incidence among male and female was similar [5]. In a few recent acute hepatitis A outbreaks in Europe the strong male predominance was observed [6]. Also in our study, most patients were male (95\%). In many European countries [6-9] most of the male patients were men who have sex with men. In the research conducted in Italy among 117 patients with acute hepatitis A, $91 \%$ were male with $66 \%$ of MSM [7]. In the Spanish study, $96 \%$ were male, among them $67 \%$ were MSM [8]. In Germany, among 38 patients, 97\% were male and $81 \%$ were MSM [9]. In our study, as in the countries mentioned above, dominated MSM patients (70\%).

Most of our patients underwent serological tests for other co-infections. Among 53 studied persons, 11 (21\%) were HIV-positive. Our results are similar to the study conducted in Italy, in which $14.5 \%$ of patients were HIV-positive [7]. In France, hepatitis A infection was noted in 3 patients receiving HIV pre-exposure prophylaxis (PrEP), suggesting their sexual contact with people living with HIV or people of unknown serological status [10]. The HAV/HIV outbreaks were reported also outside Europe. In Japan, 12 of 13 studied patients (92\%) were HIV-positive [11]. Moreover, two of our patients $(6 \%)$ had positive VDRL test, meaning recently active syphilis infection. Both of them were HIV-positive. Similarly, the study from Taiwan [12] indicated recent syphilis as the factor associated with acquiring acute hepatitis A.

Regarding laboratory results, median platelet count in studied group was $227.5 \mathrm{~K} / \mu \mathrm{l}$, and was elevated in 1 case. Initial thrombocytopenia, according to the results of the Kim et al. study [13] may suggest a more severe clinical course, longer recovery time and higher risk of complications of acute hepatitis A. Initial thrombocytopenia occurred in 4 of our patients (8\%). One patient with the lowest platelet count $(56.0 \mathrm{~K} / \mu \mathrm{l})$ had also the longest time of hospitalization in the analyzed group (12 days).

All 55 patients had elevated levels of alanine aminotransferase, aspartate aminotransferase, and gamma-glutamyltransferase. Forty six of studied patients had an elevated level of alkaline phosphatase, which may indicate a cholestatic clinical course, not necessarily leading to prolonged cholestasis, and described as an atypical manifestation [14].
The international normalized ratio was elevated in 28 patients $(50.9 \%)$. None of them was treated with INR increasing medications. Hematological complications may be the first symptoms of the disease or may not occur in the clinical course [15].

\section{Conclusions}

The recent outbreak of hepatitis A in Poland is caused mainly by HAV transmition during sexual activity, mostly among men who have sex with men. In this study, the majority of the HAV-infected patients were young males, often co-infected with other sexually transmitted diseases (STDs): syphilis, hepatitis B and/or HIV infection. Our results confirm the statement that admission to the hospital because of acute hepatitis A diagnosis is often a good opportunity to diagnose other STDs in the same patient.

\section{Conflict of interest}

The authors declare no potential conflicts of interest with respect to the research, authorship, and/or publication of this article.

\section{References}

1. WHO. The Global Prevalence of Hepatitis A Virus Infection and Susceptibility: A Systematic Review. Available at: http://apps.who. int/iris/bitstream/10665/70180/1/WHO_IVB_10.01_eng.pdf

2. Wojewódzka Stacja Sanitarno-Epidemiologiczna w Warszawie: Wzrost zachorowań na wirusowe zapalenie wątroby typu A. Available at: http://wsse.waw.pl/aktualnosci-i-komunikaty/aktualnosci/ wzrost-zachorowan-na-wirusowe-zapalenie-watroby-typu-a

3. CDC 2015 Sexually Transmitted Diseases Treatment GuidelinesViral Hepatitis. Available at: https://www.cdc.gov/std/tg2015/hepatitis.htm

4. WHO Hepatitis A Fact sheet. Available at: http://www.who.int/mediacentre/factsheets/fs328/en/

5. Polański P. Hepatitis A in Poland in 2015. Przegl Epidemiol 2017; 71: 345-349.

6. ECDC Epidemiological update: Hepatitis A outbreak in the EU/EEA mostly affecting men who have sex with men. Available at: https:// ecdc.europa.eu/en/news-events/epidemiological-update-hepatitis-outbreak-eueea-mostly-affecting-men-who-have-sex-men-2

7. Lombardi A, Rossotti R, Moioli MC, et al. The impact of HIV infection and MSM status on hepatitis A infection: the experience of two 
tertiary centres in Northern Italy during the 2017 outbreak and in the 2009-2016 period. J Viral Hepat 2019; doi: 10.1111/jvh.13082 [Epub ahead of print].

8. Rodríguez-Tajes S, Perpiñán E, Caballol B, et al. Hepatitis A outbreak in Barcelona among men who have sex with men (MSM), January-June 2017: A hospital perspective. Liver Int 2018; 38: 588-593.

9. Werber D, Michaelis K, Hausner M, et al. Ongoing outbreaks of hepatitis A among men who have sex with men (MSM), Berlin, November 2016 to January 2017 - linked to other German cities and European countries. Euro Surveill 2017; 22.

10. Penot P, Colombier MA, Maylin S, Molina JM. Hepatitis A infections in men who have sex with men using HIV PrEP in Paris. BM] Case Rep 2018; 2018. pii: bcr-2017-222248.

11. Tanaka S, Kishi T, Ishihara A, et al. Outbreak of hepatitis A linked to European outbreaks among men who have sex with men in Osaka, Japan, from March to July 2018. Hepatol Res 2019; doi: 10.1111/hepr.13314 [Epub ahead of print].

12. Chen GJ, Lin KY, Sun HY, et al. Incidence of acute hepatitis A among HIV-positive patients during an outbreak among MSM in Taiwan: Impact of HAV vaccination. Liver Int 2018; 38: 594-601.

13. Kim HS, Kim HS, Lee JY, et al. Initial thrombocytopenia as a simple, valuable predictor for clinical manifestation in acute hepatitis A. Scand J Gastroenterol 2008; 43: 81-88.

14. Jeong SH, Lee HS. Hepatitis A: clinical manifestations and management. Intervirology 2010; 53: 15-19.

15. Wrotkowska M, Stalke P, Smiatacz T, Zaucha JM. Powikłania hematologiczne u chorych na wirusowe zapalenie wątroby. Hematologia 2011; 2: 162-171. 